\title{
Jesus vandag: Moontlikhede van Ernst Troeltsch se Christologie
}

\author{
Pieter JJ Botha \\ Universiteit van Suid-Afrika
}

\begin{abstract}
Jesus today: Possibilities of the Christology of Ernst Troeltsch

The significance of the historical Jesus for faith is a major issue in the debate concerning the value of theology. Emst Troeltsch constructed a meaningful answer to both questions in terms of what he called Glaubenslehre. A discussion of his views on the value of Jesus for faith is placed in the context of his theological system. Although Troeltsch sees Jesus' significance in symbolic terms he emphasises the need for historical study, without which a symbol becomes empty. A short critical discussion of Troeltsch's significance to the contemporary debate on Christology concludes the essay.
\end{abstract}

\section{INLEIDING}

Kan die Christelik.e geloof homself verantwoord teenoor die aansprake van die rasioneel wetenskaplike denke, teenoor die ateïstiese kritiek en veral ten opsigte van die sekularistiese lewensopvatting van die moderne mens? In die brandpunt van hierdie geskil lê veral die Christologie: Aan die een kant as die finale toetssteen en aan die ander kant as een van die grootste struikelblokke.

Ernst Troeltsch is belangrik vir hierdie gesprek veral omdat die kwessie van relevante teologie en die strewe na intellektuele integriteit in geloof vir hom van ware erns was. Hy het die konflik tussen tradisionele geloof en kontemporêre wetenskap voluit gekonfronteer. Mens sou kon sê dat hy in die tradisie staan van teoloë wat wil aantoon dat die Christelike geloof redelik is en verenigbaar met moderne denke. Die dieperliggende probleem met dié soort van poging is natuurlik maklik om raak te sien, naamlik dat die aansluiting geskied op gronde van die Aufklärung se ideaal van die outonome mens - wat juis die oorsaak van die probleem in die eerste plek is! Vir Troeltsch lê die uitdaging wel hier, maar in 'n ander sin: Teologie kan net met 'n 
Christelike geloof werk wat verstaanbaar is vir die outonoom kritiese verstand van die moderne mens.

Hierdie probleem bestaan net indien erns gemaak word met die wetenskaplike voorwaardes van kennis en insig. Hoe funksioneer 'n historiese rekonstruksie - wat voldoen aan al die voorwaardes van historiese wetenskap - van dit wat ons kan weet van die Man van Nasaret binne die Christelike geloof? Daar is sekere onoorkomelike probleme, asook sekere dilemmas, wat nie weg gepraat kan word ten opsigte van die rekonstruksie van die geskiedenis van Jesus nie. Tradisionele Christelike nadenke oor hierdie probleme het geantwoord dat die historiese Jesus ò nie belangrik is vir geloof nie òf dat daar nie iets soos die historiese Jesus ('n objek van historiese navorsing) is nie. Beide reaksies is om die kritiek teen geloof toe te gee; 'n erkenning dat die Christelike godsdiens eintlik 'n buitestaander is ten opsigte van twintigste-eeuse menswees.

Ons strewe as Christene, en veral as Christelike teoloë in ons kontemporêre Westerse kultuur, behoort eerstens te wees die verstaanbaar maak van ons verhouding met God op 'n manier wat sin maak in ons wêreld. Dit behoort 'n poging te wees wat ons verhouding met God beoefen op ' $n$ manier wat aansluit by die res van ons benadering tot die lewe. 'Can it really be the mission of Christian theology to think away, so to speak, the human person, as acting, responsible, and suffering? Can theology deny subjectivity as the main reference point for theological reflection?' (Rendtorff 1985: 498; vlg Troeltsch 1913b: 235-8; Santmire 1973: 367). Net soos Immanuel Kant staan Ernst Troeltsch voor elkeen van ons: 'One cannot go around him in the attempt to recover a prior state of theological reflection; one must rather go through the critical perspective that he embodied' (Welch 1985: 267).

Troeltsch se sogenaamde relatiwistiese teologie word maklik negatief voorgestel. Gewoonlik word geredeneer dat as daar nie absolute waarheid is nie daar geen waarheid, gesag of sin kan wees nie. Vir Troeltsch is dit nie die twee opsies nie. Inteendeel, die verbasende is juis dat die befaamde radikalisme van sy standpunte hom nie weggedryf het van die Christendom nie! As mens konsekwent histories dink en dus 'n dogmatistiese grondhouding laat vaar het is die gevolg nie pessimisme nie. In die lig hiervan is dit sinnig om te kyk hoe hy die Christologiehistoriese Jesus probleem behandel met die oog daarop om perspektief op hierdie probleem te verkry (en so aspekte van ons godsdiens beter te verstaan).

Ek stel eerstens 'n kort raamwerk vir Troeltsch se denke daar, 
behandel dan sy sieninge van die verband tussen die Christelike godsdiens en Jesus, situeer dit in die konteks van sy rekonstruksie van Glaubenslehre as die enigste geldige teologiese sisteem en bespreek daarna enkele implikasies en moontlikhede.

\section{TEOLOGIE EN BETROKKENHEID}

Troeltsch se werke reflekteer besinning oor 'n verstommende wye reeks temas. Onderliggend aan verreweg die grootste deel van sy arbeid lê die motief om die godsdienstige tradisie waarbinne hy staan asook die tyd waarin hy leef, te analiseer, te verstaan en met mekaar in verband te bring: 'Mit rückhaltloserem Eingehen auf die moderne Welt die Christliche Ideen- und Lebenswelt zu durchdenken und zu formulieren' (Troeltsch 1912c: viii).

Om sy benadering en metode saam te kan vat moet ' $n$ mens dus verstaan wat hy met 'moderne wêreld' en die 'teologiese taak' bedoel.

\subsection{Moderne wêreld}

Die konstante in wat Troeltsch onder 'Neuzeit' begryp, kan maklik aangedui word: Die moderne wêreld het sy fondament in die Aufklärung en nie in die Hervorming nie (Troeltsch 1909: 141; 1912b; 1912c; 1925a: 7, 338-9).

Troeltsch het duidelik besin oor die vraag hoe ' $n$ mens by die inhoud van jou wêreldbeeld uitkom:

... to set oneself such a task implies ... an undertaking in which the constructive intelligence plays a part - the grasping together of the present under a general conception characteristic of its essence, and the comparison of this whole with the past as a group of historical factors and tendencies which have also to be described and characterised by general concepts (Troeltsch 1912b: 3).

So gesien was die era voorafgaande aan die Neuzeit 'the great period of Church-civilisation, based on the belief in an absolute and immediate Divine revelation ... above all things a civilisation of authority in the fullest sense ...' (Troeltsch 1912b: 12-3). Hierdie 'grondbeginsel' het uiteraard sekere houdings ten opsigte van die mundane meegebring, maar belangriker ook ten opsigte van wat nadenke en ondersoek betref. Omdat daar vaste sekerhede was (beliggaam in die kerk), was selfstan- 
dige denke gedemp: Daar was nie ruimte vir 'n soeke na waarheid nie en die moontlikheid van kritiese konflik - en dus ook van verandering - was uiters beperk.

Gevolglik is die verskil met die kontemporêre tyd vir Troeltsch ooglopend. Gesag moet nou gerasionaliseer word, en die onomwonde implikasie is dat individuele oortuigings, opinies, teorieë en praktiese oogmerke ontwikkel en al meer toeneem (Troeltsch 1912b: 19). Die impak van die Aufklärung is allesbeslissend. Kerklike onverdraagsaamheid (weens absolute sekerhede) en goddelike onfeilbaarheid het plek gemaak vir menslike relatiwiteit en verdraagsaamheid. Wetenskaplike denke het oorgeneem by openbaring en outonome individualiteit heers waar kerklike beheer eers bestaan het (Troeltsch 1912b: 17-25).

In hierdie ingrypende veranderinge is daar 'n sentrale (entscheidender) faktor: Die feit dat mense bewus geword het van die historiese aard van alle denke. Histories dink en verstaan is dus ' $n$ kernelement in die moderne wêreldbeeld (Troeltsch 1913b: 102 - en regdeur al sy werke).

Dit is in die lig van die alles omsluitendheid van hierdie verandering in mentaliteit, hierdie historiese bewussyn, dat gesê kan word daar is twee, mekaar uitsluitende, sieninge oor die kwessie van geloof en die interpretasie daarvan: 'One interprets Christian faith by its wider setting in history - and especially in a pluralistic history of religions while the other reads all history in the light of Christian faith' (Gerrish 1984: 46). Frei (1957: 63-64) het dus die teologiese alternatiewe vir hierdie eeu reg opgesom: 'If history is indeed the basic problem for Christocentric theology, the basic issue seems to lie far more really between Troeltsch and Barth than between Bultmann and Barth'.

Troeltsch is gekritiseer as sou hy die antitese tussen die moderne tyd en byvoorbeeld die Hervorming-era oordryf: Dat dit net sommiges in universiteitskringe is wat hierdie moderne wêreld ervaar. Verskeie voorbeelde (van aktiwiteite en oortuigings) is ook aangehaal om te wys dat die lewe maar dieselfde gebly het. Hierop het Troeltsch geantwoord dat die onvermoë van tradisionele teologie nie sal verdwyn saam met sommige professore nie. En die sogenaamde voorbeelde van nieverandering is bloot oënskynlik; van nader beskou blyk dit dat elke voorbeeld verskyn 'with new meaning and in a new form, and, above all, in a fundamentally new context' (Troeltsch 1912b: 29n).

\subsection{Teologie}

Teologie is vir Troeltsch iets wat sin en regverdiging binne die probleemkonstellasie van kerk, godsdiens en vroomheid moet vind. 
Die enigste geldige metode in die teologie is ' $n$ historiese metode (en nie 'n dogmatiese nie). Om teologie te isoleer van die ander geesteswetenskappe deur spesiale veronderstellings soos unieke Goddelike ingrypes en met behulp van eiesoortige metodes is vir eens en altyd verby. Mens kan nie a priori een opvatting of interpretasie van bogenoemde verskynsels absoluut verklaar nie: 'n Definisie of inhoud wat buite die historiese metode bepaal word, is ten slotte geen definisie of inhoud nie omdat die uniekheid en waarde van die onderskeie historiese eras misken word. Die hede en die verlede moet empiries (histories) geïnterpreteer en geanaliseer word en van daaruit moet verder besin word oor die toekoms. Etiese denke is die gereedskap van 'n teologiese konstruksie, want etiek is die fondament van teologie wat haar lei in haar perspektief op die werklikheid (Troeltsch 1913b: 552; vlg Rendtorff 1985: 476).

Daar bestaan ' $n$ redelik algemene kritiek teen Troeltsch se opvattinge naamlik dat hy die dogmatiese taak as onmoontlik verklaar het. As opmerking is dit waar, maar as kritiek irrelevant: Dit is juis wat hy probeer doen het (Troeltsch 1910a, 1913b: 516). 'n Konstruktiewe, outentieke en verstaanbare sistematiese Christelike teologie is slegs moontlik as ' $n$ alternatief vir dogmatiek (dws teologie volgens die dogmatiese metode) gevind word.

Troeltsch het in Schleiermacher se begrip van Glaubenslehre 'n konsep gevind waarmee hy teologie kon bedryf wat nie spreke oor en van God toesluier nie, maar moontlik maak. Hierdie teologie begin met godsdiens as ' $n$ fenomeen in die mens se bewussyn en as deel van die geskiedenis. Die spesifieke teologiese taak moet eers gefundeer word deur die a priori geldigheid van godsdiens en die waarde van die Christendom te beredeneer. Die uiteindelike sisteem is 'n epistemologies beskeie, uiters praktiese teologie wat die kerk dien terwyl dit ingestem is op die eise van die moderne wêreld.

Daar is ' $n$ metodologiese probleem in enige Troeltsch-interpretasie wat kortliks aandag moet kry: Watter rol moet sy Glaubenslehre (wat eers na sy dood gepubliseer is) speel en hoe verwerk 'n mens die ontwikkelinge in sy denke? Wat die Glaubenslehre betref: Ten spyte van Reist (1966: 155) se besware is dit saam met die artikels wat Troeltsch in die Religion in Geschichte und Gegenwart gepubliseer het, fundamentele dokumente om sy teologiese werk te verstaan (kyk Wyman 1983: xiv-xviii). Dit is juis omdat so min aandag aan sy konstruktiewe teologiese bydraes gegee word dat Troeltsch negatief geinterpreteer word. Wat die probleem van ontwikkeling betref: Sy onderliggende 
problematiek het baie konstant gebly ( $\mathrm{t} w$ die opbou van 'ein relativ konservatives System der Erhaltung und Sammlung unserer religiösen Kräfte auf dem Boden eines kritischen Transzendentalismus, der dem Spezifisch-Religiösen die Eingliederung in das wissenschaftliche Denken und doch die Freiheit der selbständigen Bewegung gewährt' Troeltsch 1913b: vii, 1925: 3-18). Daar is dus wel samehangendheid in sy ontwikkeling, maar uiteraard moet die biografiese konteks van elke individuele studie in ag geneem word (Apfelbacher 1978: 34-8, 90, 107-9, 223-5; Reitsema 1974: 173). Die beste indeling van Troeltsch se ontwikkeling is myns insiens Drescher (1976: 13-5, 27). Saam met Wyman (1983: xii) sien ek ook die periode 1900-1914 as die beslissende.

\subsection{Glaubenslehre}

Troeltsch se Glaubenslehre bou op 'n teologie wat die Christelike tradisies krities herformuleer om vrae van die dag te antwoord. Soos die vrae verander, moet ook die formulering van die antwoorde verander (Troeltsch 1913b: 521-2). In sy dag was die soeke nie meer na 'n genadige God nie, maar na 'Seele und Liebe', dit wil sê: Hoe 'n persoon sy menslikheid waardig en waardevol kan belewe binne die konteks van' $n$ eindelose, koue kosmos wat deel is van die ononderbroke ketting van oorsaak en gevolg. Die geskiedenis vertoon allesbehalwe 'n verbetering van mense se lot: Geen sentrum of doel is daarin sigbaar nie. In die lig van hierdie bedreigings vir menslike persoonlikheid - saam met die wat moderne tegnologie en ekonomie gebring het - wil Troeltsch die belang van godsdiens en spesifiek van die Christendom vir die Westerse mens aandui (Troeltsch 1913b: 1-7, 29-34; 1925b: 323-4). Vir hom is moderne naturalisme en materialisme die parameters van die sinvraag. Hierdie konteks is nie onbekend in Suid-Afrika vandag nie.

\section{TROELTSCH EN CHRISTOLOGIE?}

Die vraagteken by hierdie opskrif is nie sonder rede nie. Troeltsch benader teologiese probleme nie in terme van die tradisionele dogmatiek nie. Geskiedenis met ' $n$ metafisiese probleembewussyn is te verkies bo metafisiese spekulasies. Troeltsch voel teologie moet nederig wees oor sake soos triniteit en Christologie. Hy pleit om by en in die geskiedenis te bly. Die taak is historiese studie wat uitloop op waardeoordele waarmee norme vanuit die geskiedenis gevind word. Dit 
beteken egter onomwonde dat die tradisie self nooit geloofsobjek kan wees nie. (Troeltsch 1913b: 512). 'n Tradisie mag nooit met openbaring gelykgestel word nie. Gevolglik moet die twee-nature leer gelaat word. Trouens, ook Christosentrisme is onmoontlik.

It is hard to imagine a single point of history along this line [of man's history of several hundred thousand years], and that the centre-point of our own religious history, as the sole centre of all humanity ... That is in religion what geocentrism and anthropocentrism are in cosmology and metaphysics (Troeltsch 1977: 189).

Troeltsch het nie 'n uitgewerkte leer oor Jesus Christus nie - so iets sou die wese van wat hy probeer doen het, weerspreek (Apfelbacher 1978: 229). Tog was hy doelbewus Christen en juis as Christen het hy besin oor God en godsdiens.

To separate the Christian belief in God in every respect from the person of Jesus would mean to cut this belief off from all its historic roots, from every means of expounding and illustrating it, from any greatness exceeding the measure of the average individual, and thus ultimately to dissolve the belief itself (Troeltsch 1911c: 248).

Hy beywer hom vir die uitbou en verstaan van geloof in die lewendige God vir ons wat in die Europese kultuurstroom opgeneem is. Sy teologie het ' $n$ antropologiese fokus. Sonde (vervreemding van God, ervaring van sinneloosheid), verlossing, sinryke gemeenskap en veral etiek (betrokkenheid) is vir hom belangrik. Dit alles beteken dat ons sy 'Christologie' moet verstaan as 'n onderdeel van sy motivering hoekom en hoe Westerse mense godsdienstig moet wees.

\section{DIE BETEKENIS VAN DIE HISTORIESE JESUS}

In 1911 publiseer Troeltsch 'n lesing Die Bedeutung der Geschichtlichkeit Jesu für die Glauben (kyk Troeltsch 1977: 182-207). Vir hom is dit belaglik om aan die feitelikheid van Jesus te twyfel. Die belangrike vraag - wat meermale in sy werke voorkom - is die verhouding tussen die historiese Jesus en geloof. Troeltsch bied 'n sosio-psigologiese 
antwoord op die probleem in ooreenstemming met sy historiese en godsdienswetenskaplike benadering ofte wel metode.

Die historiese konteks vir hierdie problematiek is die negentiendeeeuse historiese Jesus debat, soos dit byvoorbeeld geillustreer word deur die studies van DF Strauß en Bruno Bauer. Die hele trant van die ontwikkelinge in Troeltsch se tyd was dat die historiese Jesus geen godsdienstige betekenis het nie. In 1910 in Duitsland was dit net nie gangbaar om te vra na die historiese Jesus nie (Gerrish 1975: 14). In die opsig word die teologiese atmosfeer goed weerspieël deur die werke van Martin Kähler, Johannes Weiß, Wilhelm Hermann en Georg Wobbermin. Veral is dit die invloedsfeer van Albrecht Ritschl waarbinne Troeltsch se argument dat die historiese Jesus en Christelike geloof onlosmaaklik verbonde is, verstaan moet word. Vir Troeltsch was Ritschl se interpretasie van die dogmatiese tradisie en sy interpretasie van die moderne situasie net te gemaklik harmonieus om te oortuig. Dit het, wat Troeltsch betref, gewoon nie met die feite gestrook nie.

Die direkte aanloop vir Troeltsch se studie was die tese van Arthur Drews (1910). Alhoewel Drews se standpunt dat die Jesus-verhale vrome fiksies van die Christelike gemeenskap is vir Troeltsch (1977: 184, 1913b: 36-43) 'clearly ludicrous' is, bring dit 'n ernstiger en dieperliggende probleem na vore naamlik die vraag na die logika van geloof.

Dit spreek vanself dat historiese kritiek ook die persoon van Jesus in die sfeer van onsekere en relatiewe historiese kennis bring. Gesonde en deeglike historiese ondersoek het die vraag gevra of ons genoeg kennis van Jesus kan hê om die ontstaan van die Christendom histories te verstaan. Kritiek het ook ontdek

... how very foreign was the religious and ethical stance of the early church and even of Jesus himself. They were tied to the popular world picture of antiquity, to Jewish and oriental notions and to apocalyptic eschatological ideals. The 'Christianity of Christ' was something entirely different from the Christianity of a church which had settled for compromise with science and the indispensable secular morality of political, legal and economic life (Troeltsch 1977: 183).

Die vraag kan nie uitbly nie: 'What can a picture of Jesus subject to and shaped by historical criticism mean for a faith that is by its very nature concerned with the eternal, timeless, unconditioned and supra-histori- 


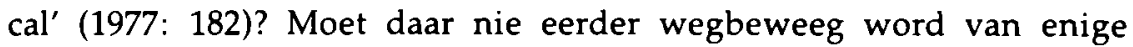
historiese verbintenis nie?

Hierdie probleem is natuurlik net 'n ernstige vraag indien geloof en verlossing kontemporêre inhoude het. 'It would be pointless if one assumed the Christianity of the early Church with its dogma of the God-man, its church and sacraments established by Christ and the redeeming effects of his saving work of reconciling God' (Troeltsch 1977: 184, 191).

Die saak staan anders wanneer mens - soos Troeltsch, asook die invloedryke groep wat hy die 'Vermittlungstheologen' genoem het Christendom sien as Glaubenserkenntnis Gottes. Vir Schleiermacher, Ritschl en Herrmann is die historiese persoon van Jesus nodig om die mens se onvermoë om te glo, te oorkom. Kennis van Jesus se persoonlikheid ontlok die idee van wat geloof behels; die indruk wat Jesus maak, maak geloof effektief.

Troeltsch sien egter verskeie probleme in hierdie standpunt. Voorop staan die problematiese siening van 'n persoonlike verhouding met Jesus, analoog met die impak van een mens op 'n ander. Hierdie 'suggestive power of [Jesus'] personality' veronderstel dat Jesus se godsdienstige persoonlikheid geken kán word. Hierdie aanname is allesbehalwe duidelik. 'Even if this way of grasping Jesus ever was a possibility it has in fact certainly been rendered impossible by modern criticism' (Troeltsch 1977: 188-9). Nie eers 'n beperking tot die hoofsake van Jesus se prediking sal help nie:

... that still does not give direct contact between one man and another. There is a good deal of alien matter to be overcome. Neither is it legitimate to say that only the recognition of Jesus as divine authority and source of certainty gives the confidence and joy of faith. These have existed and still exist without any knowledge of or specially emphasised relationship to Jesus. In fact the burden of the historical Jesus problem is as a matter of experience more likely to shatter faith than protect it (Troeltsch 1977: 189).

'n Verdere veronderstelling van hierdie standpunt is 'that a man who does not know Christ cannot come to a joyful faith in God' (Troeltsch 1977: 188). Vir Troeltsch (1980) is dit 'n ontoepaslike minagtende houding om in te neem teenoor ander godsdienstige opvattinge (kyk ook Knitter 1985: 23-33, Pye 1973). Nog erger: Dit is onhistoriese denke om Jesus en die kerk as die enigste sfere van verlossing te beskou. 'It 
goes with the idyllic small and narrow world picture of the ancients and the middle ages ... To modern man it is alien and incomprehensible because it does not fit in with his general instinctively held presuppositions' (Troeltsch 1977: 189).

As beide ortodoksie en die teoloë wat probeer om 'n middeweg te vind dan nie ' $n$ behoorlike antwoord kan gee nie lyk die konklusie onafwendbaar: Die historiese Jesus is bloot 'n toevallige winspunt vir die geloof (indien enigsins), die geidealiseerde Christus is waardevol; geloof is konsekwent ' $n$ individuele en persoonlike saak.

Hierop antwoord Troeltsch met 'n sterk nee. Die getuienis wat bestaan bevestig juis nie dat individuele geloof sigself kan onderhou deur eie vermoëns nie. Godsdienstige individualisme is utopisme: onrealisties, onprakties en parasities (Troeltsch 1910c: 1448; 1911b: $1153-4)$. Die 'one perfectly clear result of the history and psychology of religion is that in all religion what really counts is not dogma and idea but cult and community' (Troeltsch 1977: 194).

'The decisive point in evaluating the significance of Jesus is therefore not that redemption outside Christianity is impossible, but the need a religious community has for a support, centre and symbol of its religious life' (Troeltsch 1977: 202). Jesus se plek in die Christelike geloof moet verstaan word vanuit die basiese sosiale karakter van 'n lewende godsdiens. Trouens, wat Troeltsch betref, lê die armoede van die Christendom van sy tyd juis hier.

This lack of community and cult is the real sickness of modern Christianity and contemporary religious practice generally. It is what makes it so impermanent and chaotic, so dependent on who happens to be there, so much an amateur thing for enthusiasts, so much a matter of world-view and the intellect. It has no dominant centre from which it can be nourished, but just as many centres as there are sensitive individual seekers ... It is also feeble and insipid because it lacks the effect which a total spirit and fellowship has upon the individual, with its power to encourage and sustain, intensify and diversify, and above all to set practical goals for the like-minded group (Troeltsch 1977: 194).

Jesus lewe as effektiewe simbool van geloof, een van die Kraft-quellen und Konzentrationspunkte waarsonder persoonlike vroomheid verarm en lam raak en die gelowige gemeenskap nie 'n sentrum besit nie (Troeltsch 1913b: 513). Jesus is een van die godsdiensgeskiedenis se Urbilder, een van daardie 'images of personal, concrete life ... They ... 
possess a vividness and plasticity never found in theory and understanding but only in imagination and feeling' (Troeltsch 1977: 195). Christendom, met Christus as sentrum, se bestaan 'rest on socialpsychological laws which have produced exactly the same phenomena in other religious areas and recur a thousand times over on a smaller scale up to the present' (Troeltsch 1977: 196).

Jesus Christus is egter nie 'n mitiese simbool nie. Dit sou blote estetisisme wees. Die simbool moet aan die geskiedenis verbind wees. Die Grundzüge van Jesus se leer en lewe is dus allernoodsaaklik. 'This must be capable of being established by means of historical criticism as historical reality if the "symbol of Christ" is to have a firm and strong inner basis in the "fact" of Jesus' (Troeltsch 1977: 198). Troeltsch deins nie terug daarvan om die teologie weerloos voor die historiese kritiek te laat nie. 'It is a mere playing with words to hold on to the Christian principle and yet want to leave the historical questions to one side' (Troeltsch 1977: 198).

Hy noem Jesus verskeie kere die simbool van Christelike liefde, geloof, waardes en ideale. Jesus is ook die brandpunt van Christelike aanbidding van God (kultus). Die Christelike gemeenskap kan net bestaan

... through the common confession of Jesus; it is impossible to keep alive the distinctively Christian idea of God apart from seeing its life-giving embodiment in Jesus; and all the greatest and most characteristic ideas of Christianity - the idea of a grace that grasps and conquers us, of a certitude available to us, and of a superior power that elevates and overcomes us - depend on a religious appreciation and interpretation of Jesus as divine revelation (Troeltsch 1911c: 237).

Die simbool kan egter net 'n werklike simbool wees as daar agter 'n buitengewone, werklike profeet gestaan het. Diegene wat rondom Jesus wil bymekaar kom, kan net lewenskrag put uit 'n simbool wat self lewenskrag gehad het.

Die God van Jesus is geloofsobjek, Jesus is die historiese bemiddelaar en openbaarder. Christendom en Jesus is onlosmaaklik verbonde. Jesus is die brandpunt van Christelike vroomheid en aanbidding, maar hy is dit as 'n dooie: Die profeet wie se gedagtenis geëer word en wie se invloed vandag nog geldig en voelbaar is. Maar juis omdat Jesus werklik gely het, werklik gestry het vir die groot waarhede oor God het hy vandag nog mag en krag. 
Die historiese belang van Jesus is baie wyer as net die oorspronklike gebeure. Troeltsch se hele teologie berus daarop dat die kerk se verkondiging die Christus-simbool - soos in die geskiedenis van Jesus veranker - moet herinterpreteer in die lig van die volle omvang van die Christendom se geskiedenis. Tradisie is dus belangrik. 'Der Eindruck der Persönlichkeit Jesu, wie sie fortlebt, ausgedeutet von Glaubensleben unzähliger Generationen, ist es was niederbeugend und erhebend in letzter Linie dieser Gotteserkenntnis gewiß macht' (Troeltsch 1910b: 487).

Oor die opstanding van Jesus het Troeltsch - sover ek kon vasstel - nie veel gesê nie. Hy beskryf wel die ontstaangeskiedenis van die Christendom as ' $n$ 'hoffnungslose6 wissenschaftliches Problem' (Troeltsch 1925a: 69). Die geloof aan die opstanding is ' $n$ 'völlig eigentümliches Fundament' van die Christendom. 'Moderne Psychologie mag hoffen ihn verständlich zu machen' (Troeltsch 1925: 72). Op 'n ander plek sê hy dat die opstanding 'n 'Glaubens-tatsache' is wat nie deur historiese kritiek weerlê of bevestig kan word nie (1913b: 740). As ek hom reg verstaan, sou ek sê dat hy die problematiek se oorsprong sien in die konflik tussen dogmatiek wat die opstanding onttrek aan historiese ondersoek en naturalistiese geskiedskrywing sonder ' $n$ metafisiese veronderstelling wat die opstanding so by so afwys. Beide benaderings weier dus om die gebeure te verstaan en met historiese komplekse te verbind.

Die kern van die hele problematiek is die verband tussen geskiedenis en geloof. Troeltsch (1925b §6.4) sien hierdie verbintenis as sielkundig, 'lediglich psychologisch': Ons as mense kan nie ons eksistensiële honger met mitiese simbole stil nie (Troeltsch 1977: 197). Maar: Is dit nie juis so dat simbole dikwels op gronde van voorkeure gesag toegeken word, los van die geskiedenis omdat die geskiedenis 'n bedreiging vir simbole kan wees nie?

Gevolglik dink ek dat Troeltsch in die opsig net 'n deel van die probleem beantwoord het. Die geloofsproblematiek moet as verbonde aan nog 'n konteks geïnterpreteer word, naamlik persoonlike belewenis. Dit plaas die kwessie van geskiedenis in 'n wyer perspektief - en dit kan waardigheid bied aan die rol van subjektiwiteit. Troeltsch self was gekant teen die toelaat van belewenis as deel van die betekenis van geskiedenis vir geloof. Hy bespreek ervaring in ' $n$ algemene sin; nie as punktuele, individuele verskynsel nie. Tog is dit die logiese implikasie van sy argumentasie wat implisiet opgesluit lê in sy standpunt. Dink 
maar net aan sy klem op analogie as kenprinsiepe in historiese metode, en die feit dat hy verlossing koppel aan ' $n$ ervaring van vryheid.

Trouens, Troeltsch (1911c: 238) beskou die essensie van ortodokse Christologie as Christus-mistisisme wat in die Platonies-stoïsynse wêreldbeeld ingeklee is met die tradisionele twee-nature leer. Hierdie mistisisme (in ' $n$ nuwe kleed) is nie vir hom onaanvaarbaar nie. Daarom is dit vreemd dat hy nie die rol wat persoonlike ervaring speel in die inkleding van geloof meer beredeneer het nie.

Dat die geskiedenis egter ' $n$ kontrole moet wees, is in elk geval die belangrike punt. Die tekortkominge lê spesifiek hier: Presies hóě verreken mens jou ervaring in jou verstaan? Hoe kritiseer mens jou belewenisse en ervaring?

Erns met die plek wat persoonlike belewenis inneem, kan ook meer reg laat geskied aan Troeltsch se klem op die implikasie van die universaliteit van godsdienstige geloof. Troeltsch (1913b: 339) sien die gerigtheid op 'n Gegenüber as konstituerend van mens wees. Konsekwent geneem, beteken dit gewoon dat ook die Christelik geloof as Christelike godsdienstige ervaring nie 'n eksklusiewe, bo-natuurlike oorsaak het nie. Hierdie besef maak mens sommer heelwat nederiger soos wat dit betaamlik is by mense met 'n godsdienstige perspektief. Bevryding van die kramp om my eie denke en sieninge te dien en te probeer afforseer op andere, is as gevolg hiervan ' $n$ nie onaansienlike wins nie. Geloof moet as veel meer as kennis en vertroue verstaan word. Troeltsch het goed gesien dat die religieuse ervaring werklik sui generis is; iets wat totaal verskil van logiese denke en redelike insig - een van die redes hoekom Troeltsch se pogings vir my meer oortuiging besit as byvoorbeeld Pannenberg wat geloof as 'n kontinuiteit van filosofie en antropologie sien. Geloof se appèl lê in verreweg die meeste gevalle nie op die vlak van die rasionele intellek nie.

Dit is dan veral vanweë sy ontoereikende Christologie (uit hulle perspektief) waarom dialektiese en neo-ortodokse teoloë vir Troeltsch kritiseer, naas die sogenaamde redusering van teologie tot geskiedenis (vgl Ogletree 1965, Morgan 1976). Troeltsch het dit geredelik erken (dit was immers juis wat hy wou doen!) maar bo-en-behalwe die uiteensetting hoekom hy die weg ingeslaan het, het hy ook teenvrae gehad. So het hy byvoorbeeld op die 'beswaar' dat outonome redelikheid die sondeval reflekteer, gereageer met 'such a doctrine of original sin needs the courage of its convictions - the presupposition of an original perfection prior to the contamination of the world by the sin of the first couple [hy sien die Genesis-verhale as mitologies en eksemplaries - PJ] 
B] It must also develop its necessary consequence, a real redemption and decontamination' (Troeltsch 1977: 192-3). Hy het ook dikwels na die probleem van die ander godsdienste verwys as die vraag aan 'n voorstaander van finale openbaring. Al die godsdienste ontwikkel gewoonlik 'n apologetiese sisteem wat berus op identiese motiewe en prosesse (Troeltsch 1972, Pye 1976).

Daar sit ' $n$ noodwendigheid agter Troeltsch se 'antropologiese wending', 'n stuk gehoorsaamheid by wyse van spreke. Moderne denke sedert Descartes en Kant is vir eens en altyd opgeneem in die menslike subjektiwiteit en bewyssynsfeer. Dit is juis op hierdie terreine wat die ateistiese godsdienskritiek die godsbesef ontbloot het as produk van menslike projeksie, intermenslike onreg, psigologiese verdringing en dies meer. Daarom sy oortuiging dat nie in die kosmologie of ontologie nie, maar op die terrein van menslike bestaanservaring, God se bestaan en sy openbaring in Christus redelik en wetenskaplik beoordeel word.

\section{JESUS IN DIE KONTEKS VAN SY GLAUBENSLEHRE}

Troeltsch se uiteensetting moet natuurlik teen die agtergrond van sy rekonstruksie van 'n teologiese sisteem gelees en geïnterpreteer word, dit wil sê in terme van wat hy Glaubenslehre noem. 'n Duidelike formulering van die kernelemente van Glaubenslehre as sisteem vind ons in Troeltsch se artikel oor die teodisee.

Der Sinn der Welt ist die Emporbildung der Kreatur aus der von Gott ewig gesetzten Natur zur Teilhabung an seinem Wesen, was nur durch den Aufstieg der Kreatur aus der Natur zur Freiheit in Gott möglich ist. Dieser Aufstieg wiederum ist nur zu denken als eine Bildung und Erziehung durch den göttlichen Geist, der das aufstrebende Leben auf die Schranken der Endlichkeit in Leid und Sünde stoßen läßt und es dadurch zur Preisgabe der endlichen Selbstheit und zur Hingabe an das göttliche Leben leitet, so daß in den freien Persönlichkeiten nun Gottes Wille als ihr Wille Person geworden ist. Und das Ganze hat seinen Sinn darin, daß Gott selber reicher wird, wenn er sein Leben ewig ausweitet zu der Fülle der an seinem Wesen teilhabenden freien Persongeister. Darin besteht Gottes Liebe, sie ist das beständige Ausströmen und emporbilden kreatürlichen Seins zu dem eigenen freien geistigen Sein heran (Troeltsch 1913a: 1189). 
Geloof is vir hom 'n kreatiewe keuse rakende standaarde van waarheid en waardes. In ' $n$ sekere $\sin$ is dit subjektief en individueel - maar dan moet Troeltsch se groot klem op die korporatiewe karakter van godsdiens wat sentreer rondom kultus en gemeenskap, sy aandrang dat individue slegs in verhoudinge verstaanbaar is en dat verlossing nie vanuit autonomie voortspruit nie, maar vanuit die geskiedenis deur die gemeenskap kom, dadelik bygesê word. Om dus die geldigheid van die Christendom se aanspraak op waarheid te aanvaar is ' $n$ keuse. In elke waardesisteem is dit 'faith that ultimately decides; and here, too, it is likewise faith that justifies' (Troeltsch 1923: 120). Geloof as 'n keuse is 'n waagstuk, vol spanning en twyfel. Elke keuse is relatief, 'n bevestiging van waarde vir ons in hierdie spesifieke omstandighede en sal altyd opnuut, kreatief gemaak moet word.

Troeltsch kan wel in sy Glaubenslehre praat oor geloof in Jesus. Hy is sensitief vir die rol van die subjektiewe element in die konstruksie van 'n wêreldbeeld.

Jesus was the possibility of redemption. The actual redeemer remains God ... For us personally, this is how things stand: We keep to what is within reach. We place ourselves under the spell of his personality and acknowledge in him our mystical Head. Anyone who in good conscience is able to move beyond the psychological significance should do so. He will then find it easier to make the connection with orthodoxy, since he will be able to speak (in a certain sense) of the 'deity' of Christ. With respect to metaphysical interpretations we owe one another nothing except toleration (Troeltsch 1925: 117, soos vertaal deur Gerrish 1976: 131).

Maar dit is nie 'n blinde geloof nie: 'Faith can interpret facts; it cannot establish them' (Troeltsch 1977: 198).

Verlossing is vir hom die voortdurende nuwe daad van God: Praktiese kennis wat as God se openbaring binne die Christelike gemeenskap beleef word. Troeltsch sien genade as ' $n$ wisselwerkende interaksie van God en mens, 'für menschliches Denken unbegreiflichen Ineinander des Endlichen und Unendlichen' (Troeltsch 1910d: 1474).

Darin aber tritt uns nun Gott als Gnade entgegen, daß er das Selbst seine endliche Kräfte erschöpfen und sich zerbrechen läßt, um als freie schöpferische Initiative dann in uns hervorzubringen, was vorher das Selbst aus eigener Kraft gewollt hat... Die Freiheit ist 
Werk des Selbst und doch gerade als solches Werk zugleich die Selbsthingabe an ein in uns sich offenbarendes Göttliches ... Die Dialektik der Selbstverwandlung Gottes in die Kreatur löst sich wieder auf in der Dialektik der Rückverwandelung der Kreatur in Gott (Troeltsch 1910d: 1471).

Daarom het verlossing 'n sosiale konteks en is etiek so wesenlik deel van geloof - of omgekeerd gesê: Teologie moet uiters prakties en lewensgerig wees. 'Das Jenseits ist die Kraft des Diesseits' (Troeltsch 1925b: 29, 1912c: 979). Hy praat graag van die etiese persoonlikheid of gees met norme wat in sigself waarde het. (Vir sy etiek, kyk Troeltsch 1913b: 552-672; vlg ook Pannenberg 1981: 87-111.)

Die wese van die Christendom is vir Troeltsch die vraag na die integriteit daarvan. Dit kan alleenlik beantwoord word deur die ondersoeker wat die geskiedenis van die Christendom ten volle betrek. Dit is iets wat altyd opnuut beantwoord moet word, verskillend in verskillende omstandighede, maar met verantwoordelike historiese fondamente. Dit bly nogtans 'n subjektiewe keuse; 'n kombinasie van persoonlike veronderstellings, kontemporêre perspektiewe en historiese navorsing. Maar dit is juis ' $n$ 'creative act, which can only be refuted or completed and amended by a more convincing and more deeply liberating act' (Troeltsch 1977; 160). Troeltsch self het Christendom gedefinieer as 'etiese teïsme'. Dit is vanuit hierdie kern dat hy Jesus sien as relevant vir vandag: Die een wat ons die naaste aan God bring en wat aandui wat liefde, vryheid en menswaardigheid is. Die vraag is nie of Christus of Christendom absolute waarheid is nie, maar of dit waarheid bevat (Troeltsch 1980: 18, 1972: 45-62).

'For us "God in Christ" can only mean that in Jesus we reverence the highest revelation of God accessible to us and that we make the picture of Jesus the rallying point of all God's testimonies to himself found in our sphere of life' (Troeltsch 1977: 206). Jesus is dus wel 'n finale waarde, maar dit is ' $n$ relatiewe absolute, geldig alleen in terme van die Westerse kultuurstroom. 'A truth which ... is a truth for us does not cease, because of this, to be very truth and life' (Troeltsch 1980: 31). Hy verklaar en regverdig Christosentrisme sosiologies en psigologies. Anders kan dit nie: 'We have resolutely to grasp the divine as it presents itself to us in our time. In our time it presents itself in history and in the connexion of the individual's subjectivety with the substance of an overarching totality of historical life' (Troeltsch 1977: 206). 


\section{PERSPEKTIEF}

Daar lê myns insiens vele moontlikhede in die gedagtes van Troeltsch - sonder om enigsins te wil betoog dat Troeltsch se antwoorde nou die alfa en omega van teologiese probleme is. Allermins! Hyself sou geskok gewees het oor sodanige insinuasies.

Natuurlik is daar groot verskille tussen Troeltsch se dag en ons dag. Met juis dit in gedagte blyk dit myns insiens dat sy denke relevansie het vir ons vandag. Veral vir ons in Suid-Afrika met ' $n$ groeiende bewussyn van die onontkombaarheid van pluralisme en historiese gebondenheid. Hierdie sake, saam met 'n problematisering van die geloofwaardigheid van die Christelike geloof, het ingrypende invloed op teologiese wetenskap. In 'n strewe om redelik en relevant te wees is daar veel te leer - positief en negatief - by die weë wat Troeltsch ingeslaan het.

Kritiek is daar inderdaad. Historiese metode ten spyt het Troeltsch nooit by die ryke diversiteit wat in die vroeë Christendom se prediking oor Jesus lê, uitgekom nie. Mens sou ook kon verwys na sy aansluiting by filosofiese idealisme - desnieteenstaande sy kritiek op Hegel en Schleiermacher.

Daar is ' $n$ metodologiese onduidelikheid wat vanuit sy Glaubenslehre voortspruit, naamlik die verhouding tussen filosofiese en historiese teologie. Dit hang saam met sy Kantiaanse kenteorie met die kenmerkende (maar weliswaar aangrypende) metafisiese onderbou. Hierdie metafisiese 'density' (Wyman 1983: 200) is juis problematies en afgeskeep in sy sisteem. Troeltsch is geweldig duidelik en sterk in sy besinning oor geskiedenis en historiese metode terwyl sy metafisika soms vaag is, onderontwikkeld. My eie indruk aan die ander kant is dat Troeltsch eintlik doelbewus was hiermee. Sekerheid is moeilik, maar die feit bly dat hy op hierdie terrein minder rigoristies en selfs onduidelik was.

Troeltsch het egter daarin geslaag om weg te kom van sacrificium intellectus of sacrificium fidei as enigste alternatiewe vir die moderne mens en dit maak sy teologie belangrik - ten spyte van enige kritiek wat mens daarteen sou uitspreek. Dit is vanuit hierdie hoek bekyk, wat mens besef hoe ontoereikend ' $n$ groot deel van die kontemporêre debat oor die Christologie eintlik is - veral waar 'n hoë inkarnasie-Christologie voorgestaan word. (Ek sluit dus aan by Ogden 1982: 1-19 se analise van hierdie debat.)

Die 'feitelikheid' van 'n standpunt word op gesag gebaseer en nie op 
historiografie nie. Presies wie se gesag word bietjie versluier - dit word gewoonlik deur middel van die konsep 'openbaring' aan God gekoppel. 'n Bietjie nadenke wys dat dit eintlik 'n siening van geselekteerde tekste is, met ander woorde die persoon se eie gesag!

Mens se verstand deins eintlik terug voor die veronderstellings. Die metode is dikwels heel onproblematies die 'dogmatiese', of omgekeerd gesê, ' $n$ onwilligheid om histories te dink.* Alleen só kan ' $n$ mens onbewus wees van die feit dat die finaliteit van Christus, los van ' $n$ sekere Joodse geskiedbeskouing, nie sin kan maak nie. Of kan 'n mens onbewus wees van die morele kritiek teen die sigbare absolute gesag wat noodwendig voortvloei uit die oortuiging van ' $n$ absolute manifestasie van God.

Met die 'dogmatiese' metode word die moontlikhede van teologie buite die geesteswetenskaplike kring en invloedsfeer verplaas; eintlik dus buite die (hedendaagse) lewe self. Die noodwendige gevolg hiervan is dat opvattings oor geskiedenis dikwels ongelooflik naief en eenvoudig is. Amper iets soos 'n wetenskaplike verklaring wat nie wil kennis neem van Newton en Einstein nie. Dit is die ou probleem van teologie wat oor geskiedenis praat sonder om iets oor geskiedenis self iets te sê (Dyson 1974: 92). Dit gaan nie daarom dat teologie probeer om die verlede hier, na die hede te bring nie, maar primêr, in haar wese 'n lewende en kontemporêre dissipline te wees. Hier het Troeltsch baie vir ons om te leer (vlg Rendtorff 1985: 480).

'n Laaste probleem wat ek dikwels ervaar met teologiese diskussies is die onproblematiese houding ten opsigte van spreke oor God. Troeltsch hou die kernprobleem van teologie - die wese en moontlikheid van teologie self - voortdurend in die oog.

In hierdie probleme is ons almal erfgename van Schleiermacher (unser grosser Meister - Troeltsch 1913: 226). Selfs die een wat die indringendste alternatief probeer konstrueer het, het toegegee dat hy nie kon ontkom aan Schleiermacher nie (Barth, volgens Busch 1976: 493-4).

Troeltsch leer ons om te onderskei tussen vae en uiteindelik irrelevante vrae en spesifieke vrae wat ons hier en nou raak: Die wat, waarom en hoe van ons konkrete lewensprobleme. Sy idioom mag antikwaries wees, sy metode nie. Hy konstrueer 'n duidelike, same-

* Daar is gelukkig interessante uitsonderings, soos bv Fuller \& Perkins 1983; Küng 1976: 119-172 en Ogden 1982 (kyk ook Van Aarde 1987: 331-332). 
hangende en gefundeerde uiteensetting hoekom die historiese Jesus vandag aktueel is. Van alle kante poog hy om beide die waardes en die inhoude van die konsepte wat hy gebruik, kontroleerbaar te maak (met 'n induktiewe, historiese metode). In terme van die kriteria vir 'n konstruktiewe teologie ( $\mathrm{t} w$ toepaslikheid in terme van die Christelike tradisie en doelmatigheid binne kontemporêre norme van verstaanbaarheid) slaag sy poging. Die belang is die sáák wat ter sprake gebring is: "If the "language of Canaan" (Barth) is no longer convincing or even intelligible in a pluralistic and secular culture, then a theology which operates phenomenologically, without special assumptions and on the basis of the generally accepted methods of the human sciences, becomes more attractive' (Wyman 1983: 201). 'Dann kann es auch von der Theologie heißen: non scholae sed vitae, und dann kann dies ihr Leben da gefunden werden, wo es allein zu Hause ist, in einer an Zukunft, lebendige Offenbarung, steigende Klarheit und steigende Liebe glaubenden Gemeinschaft' (Troeltsch 1913b: 226).

Ten slotte: Dit is lankal tyd dat ons besef dat die geweldige rykdom van lewe en denke wat moderne historiese verstaan ontsluit, niks anders is as een van die grootste verrykings van teologiese verstaan nie - watter metodologiese probleme ook al daardeur mag ontstaan. Historisme kan nie verban of geïgnoreer word nie. Ons kan alleenlik maar leer en ontdek hoe om kreatief daarmee te lewe. 'How to do this is the question Troeltsch left as an inescapable legacy to the theology of the twentieth century' (Welch 1985: 301).

\section{Literatuurverwysings}

ALLEN, L 1980. From Dogmatik to Glaubenslehre: Ernst Troeltsch and the task of theology. Fides et Historia 12/2, 37-60.

APFELBACHER, K-E 1978. Frömmigkeit und Wissenschaft: Ernst Troeltsch und sein theologisches Programm. München: Schöningh.

BECKER, G 1982. Neuzeitliches Selbstverstandnis und Religionsphilosophie: Ein Versuch zur Troeltsch-Interpretation. NZSTh 24/1, 21-36.

BERKHOF, H 1985. 200 Jahre Theologie: Ein Reisebericht. Neukirchen-Vluyn: Neukirchener Verlag.

BUSCH, E 1976. Karl Barth: His life from letters and autobiographical texts. London: SCM.

CLAYTON, JP (ed) 1976. Ernst Troeltsch and the future of theology. Cambridge: Cambridge University Press.

CUPITT, D 1975. The finality of Christ. Theol 78, 618-29.

DRESCHER, H-G 1976. Emst Troeltsch's intellectual development, in Clayton 1976: 3-32.

DYSON, AO 1974. The immortality of the past. London: SCM.

DYSON, AO 1976. Ernst Troeltsch and the possibility of a systematic theology, in Clayton 1976: 81-99.

FREI, H 1957. Niebuhr's theological background, in P Ramsey (ed), Faith and ethics: the theology of $H$ Richard Niebuhr, 16-64. Gloucester: P Smith. 
FULLER, RH \& PERKINS P 1983. Who is this Christ? Gospel christology and contermporary faith. Philadelphia: Fortress.

GERRISH, BA 1975. Jesus, myth and history: Troeltsch's stand in the 'Christ-myth' debate. IR 55, 13-35.

GERRISH, BA 1976. Ernst Troeltsch and the possibility of a historical theology, in Clayton 1976: $100-38$.

GERRISH, BA 1982. The old Protestantism and the new: Essays on the Reformation heritage. Chicago: Chicago University Press.

GERRISH, BA 1984. Protestantism and progress: An Anglo-Saxon view of Troeltsch, in Renz \& Graf 1984: 35-53.

HUGHES, HS 1959. Consciousness and society, 229-242. London: Harvester.

JONKER, WD 1977. Christus die middelaar. Pretoria: NG Kerkboekhandel.

KLAPWIJK, J 1970. De absoluutheid van de christendom en zijn historische en sociologische gebondenheid. GTT 70, 19-33.

KLAPWIJK, J 1976. Geloof en rede in de theologie van Troeltsch en Pannenberg, in Klapwijk, J, Griffioen, S, \& Groenewoud, G (reds), Vrede met de rede? 63-83. Assen: Van Gorcum.

KNITTER, PF 1985. No other name? A critical survey of Christian attitudes toward the world religions. London: SCM.

KÜNG, H 1976. On being a Christian. Glasgow: Collins.

McGRATH, AE 1986. The making of modern German christology: From the Enlightenment to Pannenberg. Oxford: Blackwell.

MORGAN, R 1976. Ernst Troeltsch and the dialectical theology, in Clayton 1976: 33-79.

MORGAN, R 1977. Troeltsch and Christian theology, in Troeltsch 1977: 208-233.

OGDEN, S 1982. The point of christology. London: SCM.

OGLETREE, TW 1965. Christian faith and history: A critical comparison of Ernst Troeltsch and Karl Barth. New York: Abingdon.

PANNENBERG, W 1981. Ethics. Philadelphia: Westminster.

PYE, M 1973. Comparative hermeneutics in religion, in Pye $M$ \& Morgan $R$ (eds), The cardinal meaning. Essays in comparative hermeneutics: Buddhism and Christianity. The Hague: Mouton.

PYE, M 1976. Ernst Troeltsch and the end of the problem about 'other' religions, in Clayton 1976: 171-95.

REIST, BA 1966. Toward a theology of involvement: The theology of Ernst Troeltsch. London: SCM.

REITSEMA, GW 1974. Ernst Troeltsch als godsdienstwijsgeer. Assen: Van Gorcum.

RENDTORFT, T 1985. The modern age as a chapter in the history of Christianity; or, the legacy of historical consciousness in present theology. JR 65, 478-99.

RENZ, H \& GRAF FW 1984. Troeltsch-Studien. 3. Bd. Protestantismus und Neuzeit. Gütersloh: Gerd Mohn.

RUNIA, K 1984. The present-day christological debate. Leicester; IVP.

SANTMIRE, HP 1973. Ernst Troeltsch: Modern historical thought and the challenge to individual religions, in Johnson RA et al, Critical issues in modern religion, 365-99. Englewood Cliffs: Prentice Hall.

SYKES, SW 1976. Ernst Troeltsch and Christianity's essence, in Clayton 1976: 139-70.

TILLICH, P 1971. Ernst Troeltsch: Versuch einer geistesgeschichtlichen Würdigung. Gesammelte Werke. Bd 12, 166-78, Stuttgart: Evangelische Verlagswerk.

TROELTSCH, E 1909. Enlightenment. Encyclopedia of religious knowledge 4, 141-7.

TROELTSCH, E 1910a. Dogma, Dogmatik. RGG 2, 105-9.

TROELTSCH, E 1910b. Erlösung. RGG 2, 481-8.

TROELTSCH, E 1910c. Glaube. RGG 2, 1437-56.

TROELTSCH, E 1910d. Gnade Gottes: Dogmatisch. RGG 2, 1469-74.

TROELTSCH, E 1911a. Contingency. ERE 4, 87-9. 
TROELTSCH, E 1911b. Kirche: Dogmatisch. RGG 3, 1147-55.

TROELTSCH, E 1911c. On the possibility of a free Christianity, in Fifth intermational congress of free Christianity and religious progress (Berlin), proceedings and papers, 233-49. London: sl.

TROELTSCH, E 1912a. Offenbarung: Dogmatisch. RGG 4, 918-22.

TROELTSCH, E 1912b. Protestantism and progress: A historical study of the relation of Protestantism to the modern world. Boston: Beacon.

TROELTSCH, E 1912c. The Soziallehren der christlichen Kirchen und Gruppen: Gesammelte Schriften. 1. Bd. Tübingen: Mohr.

TROELTSCH, E 1913a. Theodizee: Systematisch. RGG 5, 1186-92.

TROELTSCH, E 1913b. Zur religiösen Lage, Religionsphilosophie und Ethik: Gesammelte Schriften. 2. Bd. Tübingen: Mohr.

TROELTSCH, E 1923. Christian thought: Its history and application. London: University of London Press.

TROELTSCH, E 1925a. Aufsätze zur Geistesgeschichte und Religionssoziologie. Gesammelte Schriften 4. Bd., 1-37, 65-121, 297-374, 614-50. Tübingen: Mohr.

TROELTSCH, E 1925b. Glaubenslehre nach Vorlesengungen aus dem Jahren 1911 - 1912. Munich: Duncker \& Humblot.

TROELTSCH, E 1972. The absoluteness of Christianity and the history of religions. London: SCM.

TROELTSCH, E 1977. Writings on theology and religion. London: Duckworth.

TROELTSCH, E 1980. The place of Christianity among the world religions, in J Hick \& B Hebblethwaite (eds), Christianity and other religions, 11-30. Glasgow: Collins.

VAN AARDE, AG 1987. Gedagtes oor die begin van die kerk: 'n Geskiedenis van versoenende verskeidenheid. HTS 43, 325-351.

WELCH, C 1985. Protestant thought in the nineteenth century. Vol 2, 1870 - 1914. New Haven: Yale University Press.

WYMAN, WE 1983. The concept of 'Glaubenslehre'. Ernst Troeltsch and the theological heritage of Schleiermacher. Chico: Scholars Press. 